\title{
Role of Acid Sphingomyelinase-Induced Signaling in Melanoma Cells for Hematogenous Tumor Metastasis
}

\author{
Alexander Carpinteiro ${ }^{a, b}$ Nadine Beckmann ${ }^{a} \quad$ Aaron Seitz $^{c} \quad$ Gabriele Hessler $^{\mathrm{a}}$ \\ Barbara Wilker ${ }^{a}$ Matthias Soddemann ${ }^{a}$ Iris Helfrich ${ }^{d}$ Bärbel Edelmann ${ }^{a}$ \\ Erich Gulbins ${ }^{\mathrm{a}, \mathrm{c}}$ Katrin Anne Becker ${ }^{\mathrm{a}}$
}

aDepartment of Molecular Biology, ${ }^{b} C l i n i c$ for Hematology and ${ }^{\mathrm{d} C l i n i c}$ for Dermatology, University Hospital Essen, University of Duisburg-Essen, Essen, Germany; 'Department of Surgery, University of Cincinnati College of Medicine, Cincinnati, Ohio, USA

\section{Key Words}

Tumor metastasis $\bullet$ p38 kinase $\bullet$ Ceramide $\bullet$ Sphingolipids $\bullet$ Signaling

\begin{abstract}
Background: Hematogenous metastasis of malignant tumor cells is a multistep process that requires release of tumor cells from the local tumor mass, interaction of the tumor cells with platelets in the blood, and adhesion of either the activated tumor cells or the complexes of platelets and tumor cells to the endothelial cells of the target organ. We have previously shown that the interaction of melanoma cells with platelets results in the release of acid sphingomyelinase (Asm) from activated platelets. Secreted platelet-derived Asm acts on malignant tumor cells to cluster and activate integrins; such clustering and activation are necessary for tumor cell adhesion to endothelial cells and for metastasis. Methods: We examined the response of tumor cells to treatment with extracellular sphingomyelinase or coincubation with wild-type and Asm-deficient platelets. We determined the phosphorylation and activation of several intracellular signaling molecules, in particular p38 kinase (p38K), phospholipase $\mathrm{C}_{\gamma}$ (PLC $\gamma$ ), ezrin, and extracellular signal-regulated kinases. Results: Incubation of B16F10 melanoma cells with Asm activates p38 MAP kinase (p38K), phospholipase C $\gamma$ (PLC $\gamma$ ), ezrin, and extracellular signal-regulated kinases. Co-incubation of B16F10 melanoma cells with wild-type or Asm-deficient platelets showed that the phosphorylation/activation of p38K is dependent on Asm. Pharmacological blockade of p38K prevents activation of $\beta 1$ integrin and adhesion in vitro. Most importantly, inhibition of p38K activity in B16F10 melanoma cells prevents tumor cell adhesion and metastasis to the lung in vivo, a finding indicating the importance of p38K for metastasis. Conclusions: Asm, secreted from activated platelets after tumor cell-platelet contact, induces p38K phosphorylation in tumor cells. This in turn stimulates $\beta 1$ integrin activation that is necessary for adhesion and subsequent metastasis of tumor cells. Thus, inhibition of p38K might be a novel target to prevent tumor metastasis.
\end{abstract}




\section{Cellular Physiology Cell Physiol Biochem 2016;38:01-14

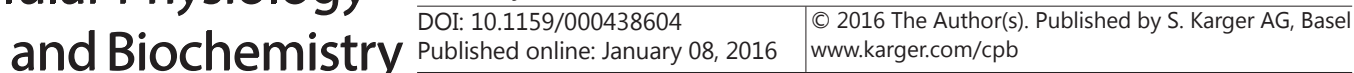 \\ Carpinteiro et al.: Acid Sphingomyelinase-Induced Signaling in Tumor Metastasis}

\section{Introduction}

Hematogenous tumor metastasis is a hallmark of the development of malignant tumors and severely affects the prognosis of a patient with a malignant tumor. Tumor metastasis is a complex, multistep process initiated by the invasion of tumor cells into blood vessels, the interaction of these tumor cells with platelets, leukocytes, endothelial cells and components of the extracellular matrix, and finally the migration of the tumor cells to a distant parenchyma [1]. The blood is a rather hostile environment for tumor cells; many of them are rapidly eliminated within the blood, in particular by natural killer (NK) cells [2-4].

The importance of the interaction of tumor cells with platelets for hematogenous metastasis is well recognized. Early studies have shown that tumor cells interact directly with platelets and that depletion of platelets or inhibition of their function leads to a decrease in metastasis [5-7]. Platelets may contribute to metastasis by accumulating on arrested tumor cells and thus protecting them from clearance by NK cells [3]. In addition, platelets may promote metastasis by facilitating tumor cell trapping and adhesion [8]. The interaction of tumor cells with platelets results in the expression and activation of adhesion molecules on the surface of the tumor cells; these molecules allow the tumor cells to bind to endothelial cells, emigrate, and metastasize [9].

We have previously shown that acid sphingomyelinase (Asm) plays a key role in this process: the contact of malignant mouse or human melanoma cells with platelets induces the rapid activation and release of secretory Asm from activated platelets. Secreted Asm binds to the surface of adjacent tumor cells and leads to the generation of ceramide. Ceramide molecules are very hydrophobic and spontaneously associate with each other to form small ceramide-enriched microdomains that fuse to large ceramide-enriched membrane platforms. Within these ceramide-enriched membrane domains of the tumor cells, activated $\beta 1$ integrin molecules cluster and mediate the adhesion of the tumor cells to vascular structures in vivo and in vitro, thus promoting metastasis [9].

Our previous results showed that integrins regulated by ceramide play a crucial role in metastasis. This effect is mainly due to differences in the adhesive properties of the tumor cells after integrin activation [9]. However, our data do not exclude that other signaling events are elicited by ceramide or that other signaling events occur prior to or in consequence of the activation of integrins. We therefore investigated a panel of intracellular signaling events, which are known to be involved in metastasis, after stimulation of tumor cells with acid sphingomyelinase, which mimics the effects of platelet secreted Asm.

Ezrin is a cytoplasmic peripheral membrane protein and belongs to the ezrin/moesin/ radixin (ERM) protein family. It serves as an intermediate between the plasma membrane and the actin cytoskeleton. It has been shown to be involved in metastasis and its function is regulated by tyrosine phosphorylation $[10,11]$. Focal adhesion kinase (FAK) is involved in various signaling pathways in cancer cells that promote cancer growth and metastasis. This includes the kinase dependent control of cell motility, invasion, cell survival and transcriptional events [12]. PLC $\gamma$ is activated by receptor and non-receptor tyrosine kinases. PLC $\gamma$ activation leads to the formation of the second messengers diacylglycerol (DAG) and inositol-1,4,5-triphosphate (IP3), which in turn activate protein kinase C (PKC) and intracellular calcium mobilization [13]. PLC $\gamma$ has been shown to be involved in cell growth, migration, and invasion [14]. Furthermore, it has been shown to be involved in the activation of integrins in leukocytes [15]. P44/42 MAPK (ERK1/2) is involved in the activation of ribosomal S6 kinases (RSK), which has been found to regulate integrin-activation and signaling $[16,17]$. P38K has been shown to be involved in the trans-endothelial migration of neutrophils [18] and colon cancer cells [19]. P38K in conjunction with PI3K has been shown to be involved in the activation of $\alpha 5 \beta 1$ integrins in colon carcinoma cells after stimulation with P-selectin [20]. Furthermore, it has been shown that p38alpha-heterozygous mice have significantly less metastasis of B16 melanoma and Lewis lung carcinoma cells into the lung in an experimental mouse model of hematogenous metastasis [21]. JNK belongs to the MAPK family 


\section{Cellular Physiology Cell Physiol Biochem 2016;38:01-14 \begin{tabular}{l|l|l} 
and Biochem 10.1159/000438604 & $\begin{array}{l}\text { (c) 2016 The Author(s). Published by S. Karger AG, Basel } \\
\text { www.karger.com/cpb }\end{array}$
\end{tabular} \\ Carpinteiro et al.: Acid Sphingomyelinase-Induced Signaling in Tumor Metastasis}

and is mainly activated during cellular stress stimuli. However, JNK is also involved in $\beta 1$ integrin-mediated leukocyte migration on fibronectin [22].

However, intracellular signaling mechanisms elicited by ceramide and the involvement of such ceramide-controlled intracellular signaling pathways in tumor metastasis are unknown. Ceramide has been shown to bind to several intracellular molecules, in particular cathepsin D [23], phospholipase $A_{2}$ [24], kinase suppressor of Ras [25], ceramide-activated protein serine/threonine phosphatases (CAPPs) [26], protein kinase C isoforms [27, 28], light chain IIIB (LCIIIB), and protein phosphatase 2A-inhibitor $2[29,30]$. Thus, ceramide can directly stimulate signaling pathways that may be involved in tumor cell metastasis.

Here, we investigated whether generating ceramide within the plasma membrane generates specific signaling events in mouse and human melanoma cells and whether at least some of these events are required for tumor metastasis. To generate ceramide within the plasma membrane, we added exogenous acid sphingomyelinase, which mimics the effects of secreted Asm. We found that treating melanoma cells with exogenous Asm activates multiple intracellular signaling events, including p38 kinase (p38K). Furthermore, we show that the stimulation of $\mathrm{p} 38 \mathrm{~K}$ is necessary for the adhesion of tumor cells to lung endothelial cells and for pulmonary metastasis of tumor cells in vivo.

\section{Materials and Methods}

Mice

Asm (Smpd1)-deficient mice and syngeneic wild-type (WT) littermates were bred on a C57BL/6 (Jackson Laboratory, Bar Harbor, ME) background. Mice were bred and housed in the vivarium of the University of Duisburg-Essen, Germany, or the University of Cincinnati, USA, under specific pathogenfree conditions as recommended by the Federation of European Laboratory Animal Science Associations (FELASA; 2002). All procedures performed on mice were approved by the Animal Care and Use Committee of the Bezirksregierung Düsseldorf, Düsseldorf, Germany, or local committees. This study used female mice aged 6 to 7 weeks.

\section{Mouse platelet isolation}

Blood was obtained by tail vein puncture and was collected into a tube containing $0.38 \%$ sodium citrate (as an anticoagulant) in $9 \mathrm{~mL}$ phosphate-buffered saline (PBS: $137 \mathrm{mM} \mathrm{NaCl}, 2.7 \mathrm{mM} \mathrm{KCl}, 10 \mathrm{mM}$ sodium phosphate dibasic, and $2 \mathrm{mM}$ potassium phosphate monobasic; pH 7.2), supplemented with $3.5 \%$ fatty acid-free bovine serum albumin (BSA; Roth, Karlsruhe, Germany). After incubation for $15 \min$ at $37^{\circ} \mathrm{C}$, samples were centrifuged at $120 \times \mathrm{g}$ without brake for $20 \mathrm{~min}$ at room temperature. The supernatant was collected, and platelets were pelleted by centrifugation at $1340 \times \mathrm{g}$ for $10 \mathrm{~min}$. Platelets were washed in Tyrode's buffer consisting of $134 \mathrm{mM} \mathrm{NaCl}, 0.34 \mathrm{mM} \mathrm{Na}_{2} \mathrm{HPO}_{4}, 2.9 \mathrm{mM} \mathrm{KCl}, 12 \mathrm{mM} \mathrm{NaHCO}, 20 \mathrm{mM}$ HEPES, 5 $\mathrm{mM}$ glucose, and $1 \mathrm{mM} \mathrm{MgCl}_{2}$. The isolated platelets were immediately used for co-incubation experiments.

\section{Isolation of human platelets}

Human blood samples were obtained from healthy volunteers (with the permission of the Ethics Commission of the University of Duisburg-Essen; Nr. 05-2768). The blood was anti-coagulated with citrate, diluted in $45 \mathrm{~mL}$ PBS supplemented with 3.5\% BSA, carefully mixed, and incubated for 20 min at $37^{\circ} \mathrm{C}$. Leukocytes and erythrocytes were pelleted by centrifugation at $100 \times \mathrm{g}$ for $20 \mathrm{~min}$. Next, $50 \mathrm{nM}$ prostaglandin E1 (PGE1; Sigma) was added to the supernatant to prevent activation, and the samples were centrifuged at $600 \times \mathrm{g}$ for $10 \mathrm{~min}$ at room temperature. Pellets were resuspended in $5 \mathrm{~mL}$ of Tyrode's buffer containing $50 \mathrm{nM}$ PGE1 and centrifuged again at $600 \times \mathrm{g}$ for $8 \mathrm{~min}$ at room temperature. The platelets were then resuspended in Tyrode's buffer. Platelets were counted, centrifuged at $250 \times \mathrm{g}$ for 8 min at room temperature, and resuspended in Tyrode's buffer at a density of $4 \times 10^{8} / \mathrm{mL}$.

\section{Cell culture}

B16F10 melanoma cells were cultured in Gibco Minimum Essential Medium (MEM; Invitrogen, Karlsruhe, Germany) supplemented with 10 mM HEPES (pH 7.4, Carl Roth GmbH, Karlsruhe, Germany), $2 \mathrm{mM}$ L-glutamine, $1 \mathrm{mM}$ sodium pyruvate, $100 \mu \mathrm{M}$ nonessential amino acids, $100 \mathrm{U} / \mathrm{mL}$ penicillin, 100 


\section{Cellular Physiology Cell Physiol Biochem 2016;38:01-14 \begin{tabular}{l|l} 
and Biochemistry Published online: January 08, 2016 & $\begin{array}{l}\text { DO 2016 The Author(s). Published by S. Karger AG, Basel } \\
\text { www.karger.com/cpb }\end{array}$
\end{tabular} \\ Carpinteiro et al.: Acid Sphingomyelinase-Induced Signaling in Tumor Metastasis}

$\mu \mathrm{g} / \mathrm{mL}$ streptomycin (all from Invitrogen) and $10 \%$ fetal calf serum (PAA Laboratories GmbH, Coelbe, Germany). To prevent selection and overgrowth of specific clones, all cultures were re-established from a frozen sample after 4 weeks. Human melanoma (HM) UKRV-Mel-06a cells were grown in RPMI 1640 supplemented with $10 \%$ fetal calf serum (FCS), L-glutamine ( $2 \mathrm{mM})$, and penicillin/streptomycin solution ( $5 \mathrm{U} / \mathrm{mL}$; all from PAA Laboratories $\mathrm{GmbH}$ ) and were split every 3 days to ensure consistent proliferation behavior. Cells were maintained at $37^{\circ} \mathrm{C}$ and $5 \% \mathrm{CO}_{2}$.

\section{In vivo metastasis}

B16F10 melanoma cells were brought into suspension by treatment with cell dissociation solution (Gibco, Life Technologies, Paisley, UK) and washed extensively in PBS. $1 \times 10^{5}$ B16F10 cells were injected in a volume of $200 \mu \mathrm{L}$ into each mouse via the tail vein. In some experiments tumor cells were treated with the specific p38K inhibitor SB239063 $(10 \mu \mathrm{M})$ for $15 \mathrm{~min}$ and washed as above before injection.

The number of tumor metastases in the lung was determined 14 days after injection by counting macroscopically visible metastases in serial sections $1 \mathrm{~mm}$ thick.

\section{In vivo adhesion/trapping of tumor cells in the lung}

B16F10 melanoma cells were labeled for $48 \mathrm{~h}$ with $1 \mu \mathrm{Ci} / \mathrm{mL}{ }^{3} \mathrm{H}$-thymidine $(185 \mathrm{GBq} / \mathrm{mmol}$; Hartmann Analytic GmbH, Braunschweig, Germany) and washed 3 times in HEPES/saline (H/S) buffer consisting of $132 \mathrm{mM} \mathrm{NaCl}, 20 \mathrm{mM}$ HEPES ( $\mathrm{pH}$ 7.4), $5 \mathrm{mM} \mathrm{KCl}, 1 \mathrm{mM} \mathrm{CaCl}{ }_{2}, 0.7 \mathrm{mM} \mathrm{MgCl}_{2}$, and $0.8 \mathrm{mM} \mathrm{MgSO}_{4}$. The cells were then intravenously injected into mice, and the mice were sacrificed after $30 \mathrm{~min}$. The lungs were flushed for 2 min with $0.9 \% \mathrm{NaCl}$ and were then removed and homogenized. The level of radioactivity in the lung was determined by liquid scintillation counting. If indicated, B16F10 cells were pretreated with the specific p38K inhibitor SB239063 $(10 \mu \mathrm{M})$ as described above.

\section{Stimulation, lysis, and Western blots}

Melanoma cells were brought into suspension by treatment with cell dissociation solution (Gibco, Life Technologies, Paisley, UK), washed extensively, and resuspended in H/S. $1 \times 10^{5}$ B16F10 or HM cells were then stimulated for different times with $5 \mathrm{U} / \mathrm{mL}$ acid sphingomyelinase purified from human placenta (Sigma) or co-incubated with $5 \times 10^{7}$ wild-type or Asm-deficient platelets, respectively. B16F10 cells or platelets alone were used as controls.

Stimulation was terminated by lysis in a buffer consisting of $25 \mathrm{mM}$ Tris- $\mathrm{HCl}$ (pH 7.4), $125 \mathrm{mM} \mathrm{NaCl}$, $10 \mathrm{mM}$ EDTA, $10 \mathrm{mM}$ sodiumpyrophosphate, 3\% IGEPAL, and $10 \mu \mathrm{g} / \mathrm{mL}$ each of aprotinin and leupeptin (TN3/AL). The solution was left on ice for $5 \mathrm{~min}$, centrifuged at $18,000 \times \mathrm{g}$ at $4^{\circ} \mathrm{C}$ for $5 \mathrm{~min}$ for pelleting insoluble material, and added to $5 \times$ sodium dodecyl sulphate (SDS) sample buffer. Samples were boiled, separated on $7.5 \%$ to $10 \%$ SDS-polyacrylamide gel electrophoresis (PAGE) gels, blotted onto nitrocellulose membranes, and blocked with $4 \%$ BSA in PBS for $45 \mathrm{~min}$. The blots were incubated with $1 \mu \mathrm{g} / \mathrm{mL}$ of one of the following primary antibodies: anti-phospho-PLC $\gamma$ (phospholipase C gamma), anti-phospho-p38K, antiphospho-Ezrin, anti-phospho-ERK (extracellular signal-related kinase), anti-phospho-JNK (c-Jun N-terminal kinase), anti-phospho-FAK (focal adhesion kinase), anti-phospho-PI3K (phosphoinositide 3-kinase), or anti-phospho-Akt (protein kinase B; all from Cell Signaling, Danvers, Massachusetts, U.S.A). Actin blots of aliquots served as loading controls (anti-actin antibodies were from Santa Cruz Inc., Dallas, Texas, U.S.A.).

Membranes were incubated with primary antibodies for $60 \mathrm{~min}$ at room temperature, washed 6-times in Tris-buffered saline (TBS) supplemented with $0.05 \%$ Tween 20, incubated for 60 min with alkaline phosphatase (AP)-coupled secondary antibodies (all diluted 1:25,000-fold, Santa Cruz Inc.), and developed with a chemoluminescence system.

\section{Adhesion assays}

$4 \times 10^{5}$ B16F10 or HM cells were pre-incubated with $10 \mu \mathrm{M}$ SB239063 for 15 min or incubated with DMSO in the respective concentration as control and then stimulated with $5 \mathrm{U} / \mathrm{mL}$ Asm (Sigma) for $5 \mathrm{~min}$ at $37^{\circ} \mathrm{C}$. After the addition of $500 \mu$ fully supplemented MEM medium, tumor cells were transferred to fibronectin-coated glass cover slips (Biopure) in 24-well plates (Falcon, BD Biosciences) for $60 \mathrm{~s}$ at $37^{\circ} \mathrm{C}$. Unbound tumor cells were washed away with PBS (pH 7.4), and cells were fixed with $2 \%$ buffered PFA for $15 \mathrm{~min}$. After being washed with PBS for $5 \mathrm{~min}$, adherent cells were analyzed with a Leica fluorescence microscope counting the number of adherent tumor cells on the coverslip (diameter $12 \mathrm{~mm}$ ).

\section{KARGER}




\section{Cellular Physiology Cell Physiol Biochem 2016;38:01-14 \begin{tabular}{ll|l} 
DOI: 10.1159/000438604 & $\begin{array}{l}\text { O } 2016 \text { The Author(s). Published by S. Karger AG, Basel } \\
\text { www.karger.com/cpb }\end{array}$ \\
\hline and Biochemistry & Published online: January 08, 2016
\end{tabular}}

Analysis of active $\beta 1$ integrin in human melanoma cells

Human melanoma cells were collected as described above, washed in H/S buffer and stimulated for 5 minutes with $5 \mathrm{U} / \mathrm{mL}$ purified Asm (Sigma) or left untreated. Before stimulation, cells were pre-incubated with $10 \mu$ M SB239063 to inhibit p38K or with DMSO 1:1000 as control. The stimulation was stopped by adding ice cold H/S buffer, cells were washed twice in ice cold H/S buffer, incubated for 30 min with $1 \mu \mathrm{g} / \mathrm{mL}$ anti-active $\beta 1$ integrin antibody (clone: HUTS-4; Millipore), washed again twice in ice cold H/S buffer and stained for 30 min with FITC-coupled anti-mouse antibodies. Cells were washed, resuspended in ice cold H/S buffer and analyzed on a Becton Dickinson FACS calibur.

\section{Statistical Analyses}

Data are presented as arithmetic means \pm SD. Samples were tested for normal distribution with the David-Pearson-Stephens test. Differences were examined for statistical significance with $t$-test or Tukey's test, as indicated in the figure legends. All data were obtained from independent measurements.

\section{Results}

Treatment of murine or human melanoma (HM) cells with sphingomyelinase induces intracellular signaling events

First, we investigated Asm/ceramide-controlled protein tyrosine phosphorylation within melanoma cells as a first sign of activating signaling transduction. Stimulation of B16F10

Fig. 1. Acid sphingomyelinase phosphorylates/activates multiple intracellular signaling molecules in murine and human melanoma cells. B16F10 or human melanoma (HM) cells were stimulated for the indicated times with $5 \mathrm{U} / \mathrm{mL}$ Asm, lysed, separated on sodium dodecyl sulphate polyacrylamide gel electrophoresis (SDS-PAGE) gels, blotted and analyzed for the indicated proteins. Actin blots of aliquots served as loading controls. (A) Samples were analyzed for phosphorylation of tyrosine residues with the antiphosphotyrosine antibody, clone 4G10. (B-E) Western blot analyses for phospho-PLC $\gamma$ (B), phosphop38K (C), phospho-Ezrin (D), or phospho-Erk (E) were performed with phospho-specific antibodies. The results are representative of 3 separate experiments each.

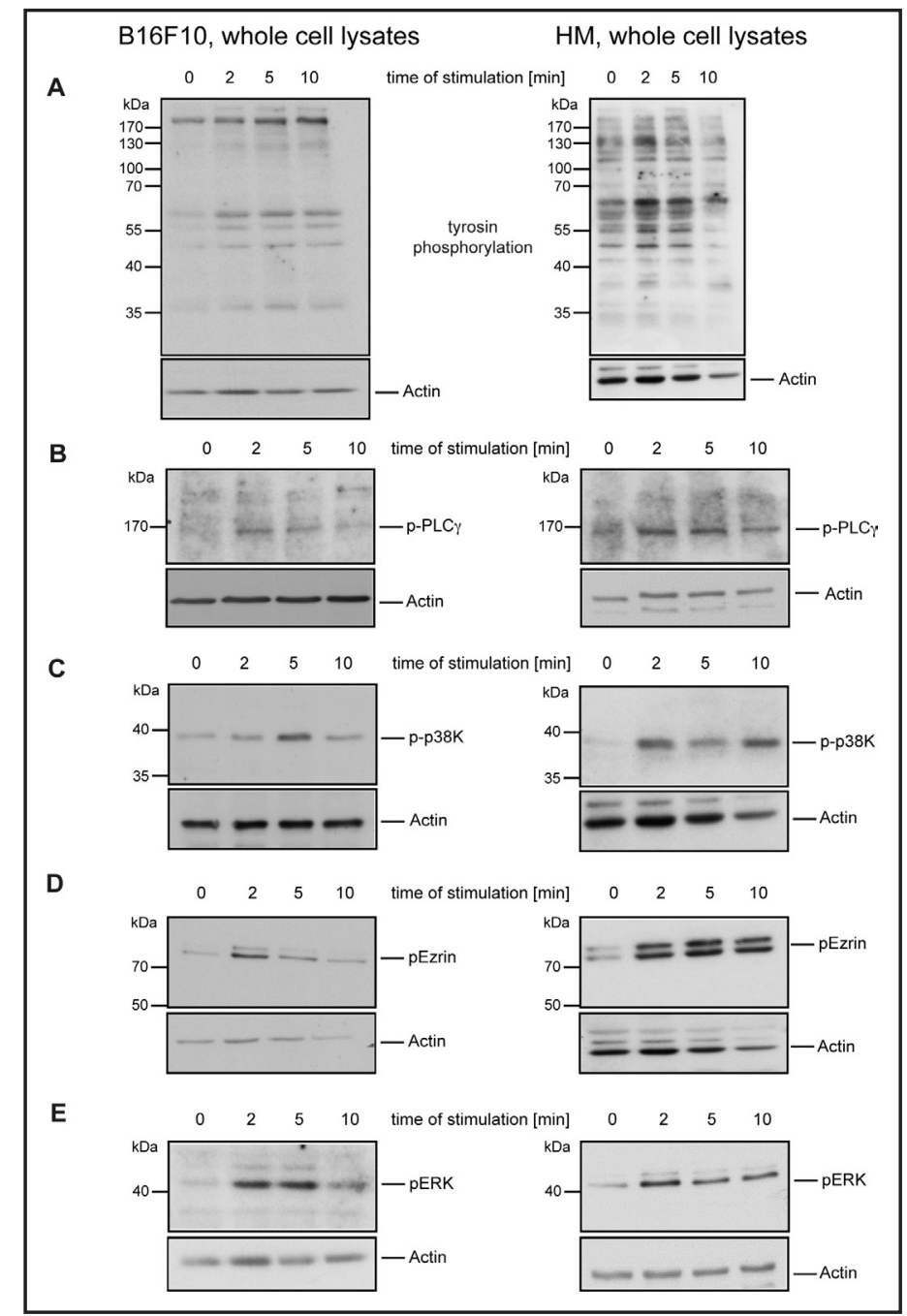




\section{Cellular Physiology Cell Physiol Biochem 2016;38:01-14 and Biochemistry Published online: January 08, $2016 \quad \begin{aligned} & \text { DOI: 10.1159/000438604 } 2016 \text { The Author(s). Published by S. Karger AG, Basel } \\ & \text { www.karger.com/cpb }\end{aligned}$ \\ Carpinteiro et al.: Acid Sphingomyelinase-Induced Signaling in Tumor Metastasis}

Fig. 2. Acid sphingomyelinase does not induce phosphorylation of JNK, FAK, PI3K, or c-Jun. (AD) B16F10 or human melanoma (HM) cells were stimulated with 5 $\mathrm{U} / \mathrm{mL}$ Asm for the indicated times. Phosphorylation of JNK (A), PI3K (B), FAK (C), and c-Jun (D) was determined with phosphorylation-specific antibodies. Actin blots of aliquots served as loading controls. The results are representative of 3 similar experiments.

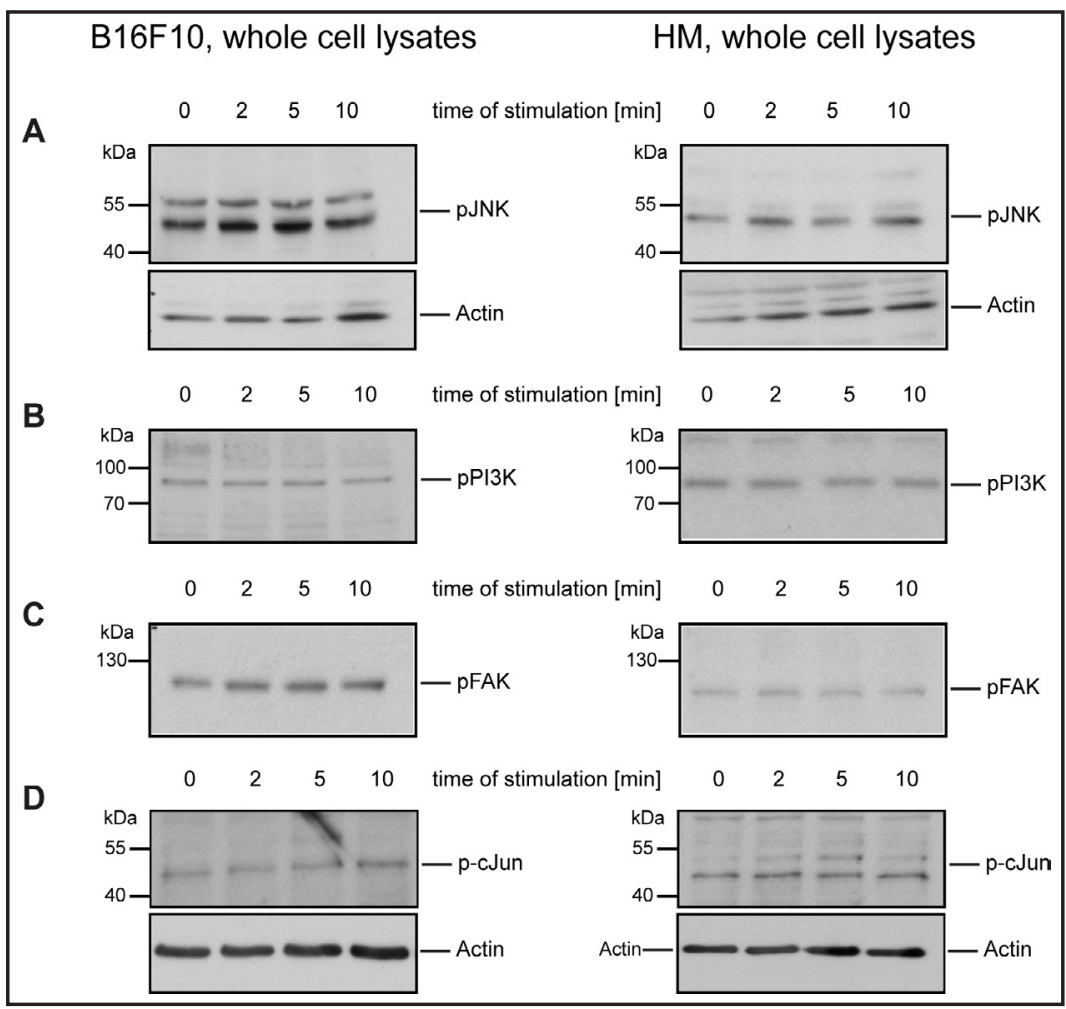

or human melanoma (HM) cells with exogenous acid sphingomyelinase resulted in tyrosine phosphorylation of several cellular proteins in B16F10 and HM cells, as evidenced by the analysis of tyrosine phosphorylation in whole-cell lysates (Fig. 1A). In addition, we observed tyrosine-phosphorylation of PLC $\gamma$ (Fig. 1B) and serine/threonine phosphorylation of stressactivated protein kinases p38K (Fig. 1C), ezrin (Fig. 1D), and ERK (Fig. 1E). In contrast, we did not detect an increase of phosphorylation as an indicator of the activation of JNK (Fig. 2A), PI3K (Fig. 2B), or FAK (Fig. 2C) in melanoma cells treated with sphingomyelinase. Consistent with the lack of JNK activation in these cells, we also did not detect the phosphorylation/activation of c-Jun (Fig. 2D) after sphingomyelinase treatment. Finally, treatment with extracellular sphingomyelinase also induced a decrease in the phosphorylation of Akt (Fig. 3 ), a finding suggesting that this kinase is inactivated by sphingomyelinase-generated ceramide.

\section{P38 kinase is required for B16F10 metastasis in vivo}

Our former results show that acid sphingomyelinase is secreted by platelets and acts on the cell surface of tumor cells to generate ceramide [9]. Therefore, we investigated several signaling events after co-incubation of tumor cells with wild-type or Asm-deficient platelets. In accordance with our findings with B16F10 and HM cells exposed to exogenous sphingomyelinase, we also detected the activation of p38K in B16F10 melanoma cells upon co-incubation with wild-type platelets, whereas the activation of p38K was much less pronounced after the incubation of B16F10 cells with Asm-deficient platelets (Fig. 4A), a finding indicating that Asm plays an important role in the activation of $\mathrm{p} 38 \mathrm{~K}$ in melanoma cells in the co-incubated samples. We observed no differences in the phosphorylation/activation of ezrin or FAK upon incubation of B16F10 cells with wild-type or Asm-deficient platelets (Fig. 4B), a finding indicating that these signaling events, although generated by exogenous sphingomyelinase, can be also activated independently of Asm upon the contact of platelets with B16F10 cells.

To determine the role of $\mathrm{p} 38 \mathrm{~K}$ activation in tumor metastasis, we used the specific inhibitor SB239063 to inhibit the activity of this kinase in $\left[{ }^{3} \mathrm{H}\right]$-thymidine-labeled B16F10 


\section{Cellular Physiology Cell Physiol Biochem 2016;38:01-14 \begin{tabular}{cc|cc} 
DOI: 10.1159/000438604 & O 2016 The Author(s). Published by S. Karger AG, Basel \\
wwwkargercom/cph
\end{tabular} \\ Carpinteiro et al.: Acid Sphingomyelinase-Induced Signaling in Tumor Metastasis}

Fig. 3. Acid sphingomyelinase treatment mediates the dephosphorylation of Akt in murine and human melanoma cells. B16F10 or human melanoma (HM) cells were incubated with $5 \mathrm{U} / \mathrm{mL}$ Asm, and the phosphorylation of Akt (protein kinase B) was measured with anti-phospho-

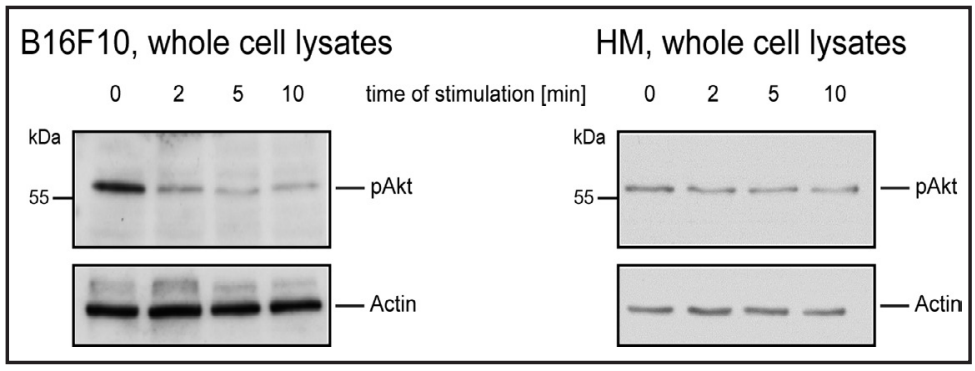

Akt (Thr308) antibodies. Aliquots were analyzed for actin and served as loading controls. The results are representative of 3 similar experiments.

Fig. 4. Co-incubation of B16F10 melanoma cells with wild-type but not with acid sphingomyelinase-deficient platelets results in phosphorylation/activation of p38K. (A) B16F10 melanoma cells were co-incubated with wild-type (WT) or acid sphingomyelinase (Asm) deficient platelets for $5 \mathrm{~min}$. Controls were B16F10 cells or platelets alone. Cells were lysed, separated on $10 \%$ SDS-PAGE gels, and analyzed for phosphorylation of p38K with activation-specific anti-phospho-p38K antibodies. Actin blots of aliquots served as loading controls. The results are representative of 3 similar experiments. (B) Phosphorylation of Ezrin and FAK does not change when B16F10 cells are co-incubated with wild-type (WT) or acid sphingomyelinase (Asm) deficient platelets. Actin blots of aliquots served as loading controls. The results are representative of 3 similar experiments.

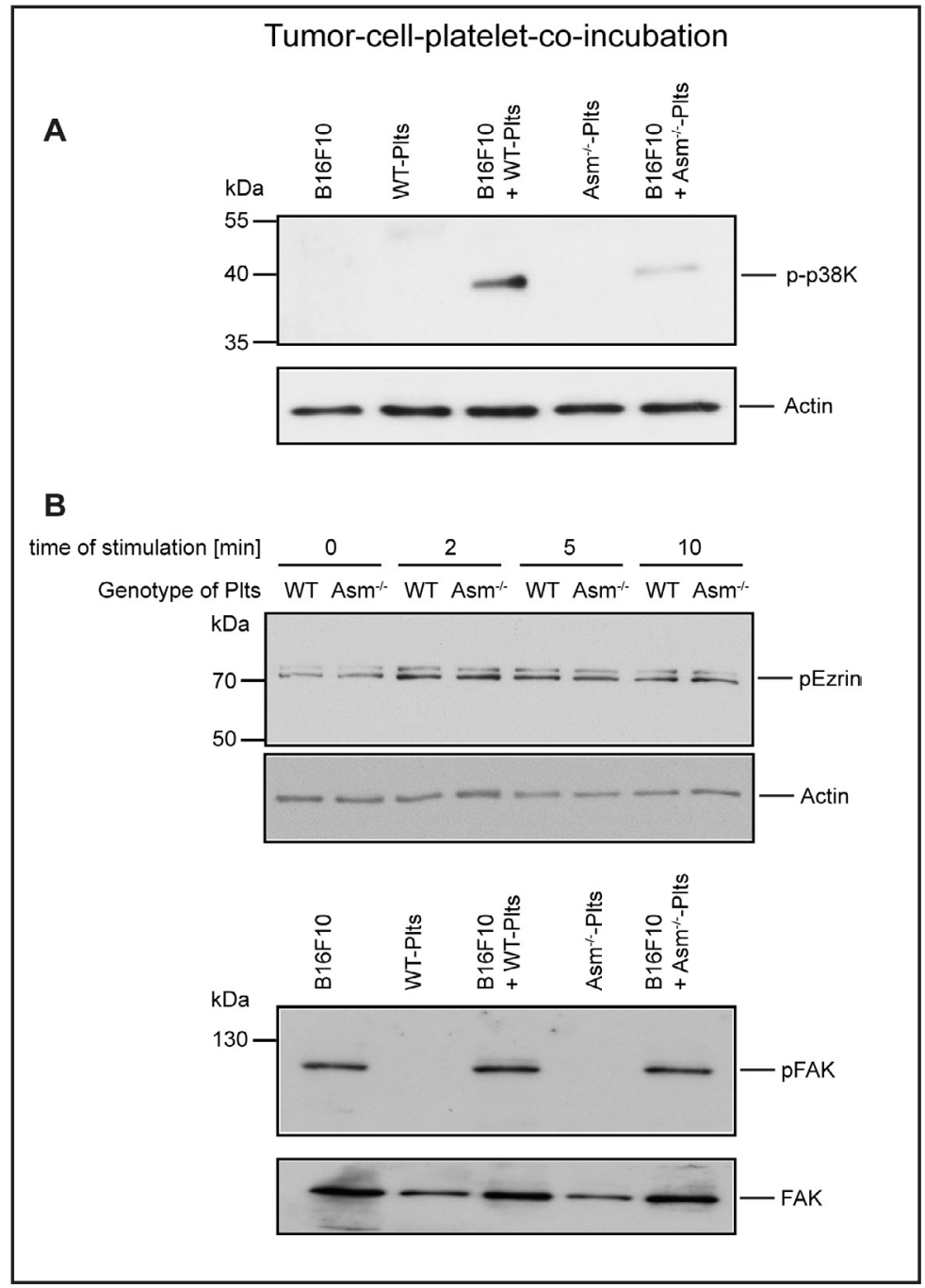

tumor cells. Since tumor cells rapidly adhere to the endothelial cells in the lung, we investigated tumor cell trapping 30 minutes after injection. The results show that pre-incubating the tumor cells with $10 \mu \mathrm{M}$ SB239063 prevents adhesion and trapping of the tumor cells in the lung in vivo (Fig. 5).

Furthermore, we injected mice with B16F10 cells that had been pre-incubated with 10 $\mu$ M SB239063 for 15 min and determined tumor metastasis to the lungs in vivo after 14 days, when adherent tumor cells formed metastases that were macroscopically visible. Inhibition 


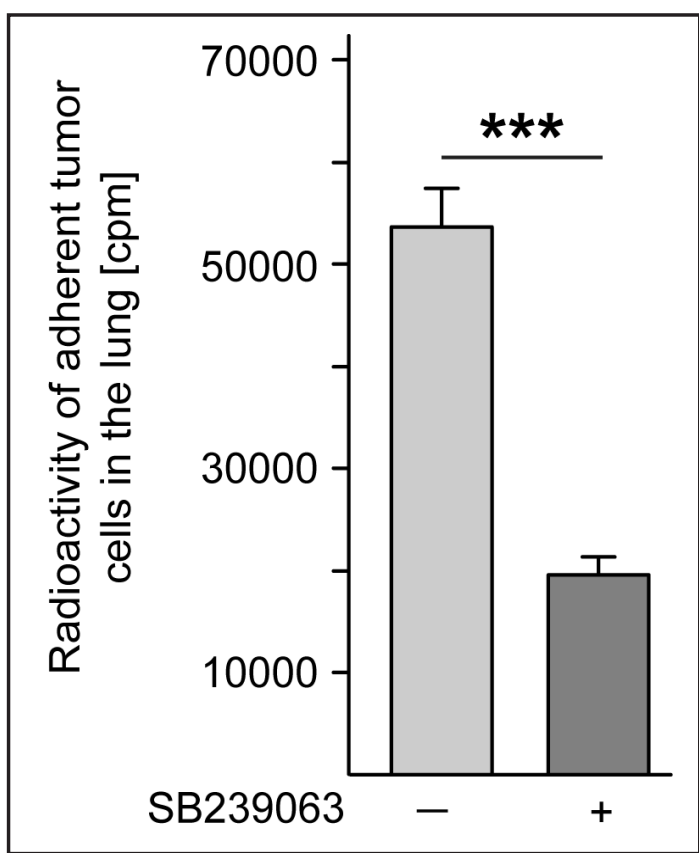

Fig. 5. Inhibition of p38K activity prevents trapping of B16F10 melanoma cells in the lungs in vivo. To define the role of p38 kinase (p38K) activation in B16F10 cells exposed to acid sphingomyelinase (Asm) deficient or wild-type (WT) platelets, we determined the trapping of tumor cells in the lungs. We treated ${ }^{3} \mathrm{H}$-thymidine-labeled B16F10 tumor cells with the specific p38K inhibitor SB239063 (10 $\mu \mathrm{M})$ for $15 \mathrm{~min}$ or the solvent $0.001 \%$ DMSO or left the cells untreated. We then intravenously injected these cells into WT mice and determined the level of radioactivity in the lungs after $30 \mathrm{~min}$. The results showed that the inhibition of the activity of p38K prevents the adhesion of B16F10 melanoma cells in the lung. Shown is the mean \pm SD of counts per minute (cpm) in lung lysates from 3 independent experiments. The statistical significance of differences in cpm between untreated and treated samples was determined by t-test. ${ }^{* * *}, \mathrm{p}<0.001$.

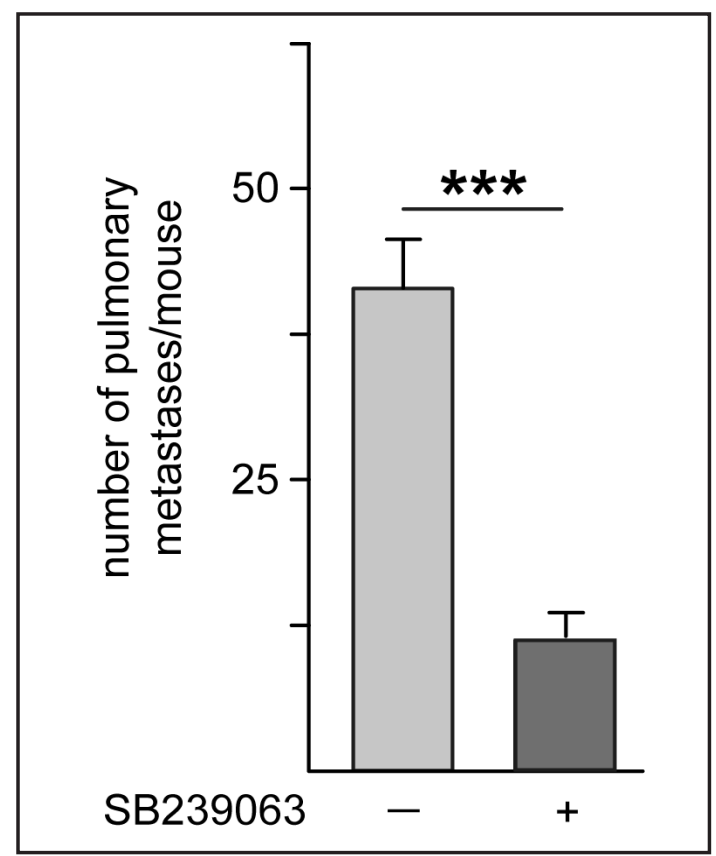

Fig. 6. Inhibition of p38K activity in B16F10 melanoma cells prevents lung metastasis. To determine whether the inhibition of p38 kinase (p38K) activity by SB239580 also prevents the metastasis of B16F10 melanoma cells to the lung, we pretreated the tumor cells ex vivo with SB239063, washed the cells, intravenously injected $1 \times 10^{5}$ B16F10 melanoma cells into wild-type (WT) mice, and determined the number of metastases in the lung after 14 days. The number of tumors in the lung was determined by counting macroscopically visible metastases in serial sections 1 mm thick. The results showed that tumor metastasis is almost completely abrogated by the inhibition of p38K activity. Shown is the mean \pm SD of 5 separate experiments. The statistical significance of differences in metastasis between untreated and treated samples was determined by $t$-test. ${ }^{* * *}, \mathrm{p}<0.001$.

of p38K activity in B16F10 melanoma led to a significant decrease in the number of tumor metastasis in vivo (Fig. 6).

\section{P38 kinase is responsible for tumor cell adhesion via $\beta 1$ integrin activation}

To gain insights into the mechanism of p38K mediated metastasis of B16F10 melanoma cells, we determined whether $\mathrm{p} 38 \mathrm{~K}$ regulates Asm derived cell adhesion. Therefore, we stimulated B16F10 and human melanoma cells with Asm in presence or absence of SB239063 and determined adhesion of tumor cells on fibronectin covered glass cover slips. We found that, in accordance to our previous data [9], Asm promotes adhesion of B16F10 melanoma and HM cells on fibronectin covered glass cover slips. This effect was completely prevented by inhibition of p38K with SB239063 (Fig. 7A + B) indicating that p38K functions upstream of $\beta 1$ integrin. Furthermore, SB239063 inhibited the activation of $\beta 1$ integrin in human 
Fig. 7. Stimulation of tumor cells with Asm promotes the adhesion to fibronectin coated glass cover slips and the activation of $\beta 1$ integrins on the cell surface, both effects are abolished by p38K inhibition. 4 x 105 B16F10 melanoma cells (A) or HM cells (B) were stimulated for 5 minutes with $5 \mathrm{U} /$ mL Asm or with H/S buffer as control, SB239063 was added when indicated. Tumor cells were then incubated for 60 seconds on fibronectin coated cover slips, washed extensively, fixed, and adhesion of tumor cells was determined. The graphs display the mean \pm SD of tumor cells adhering to fibronectin coated cover slips from one representative of at least 4 independent experiments. Each experiment was performed in triplicates. Statistical significance was determined by analysis of variance (ANOVA), $* * * \mathrm{p}<0.001$. For pairwise comparisons, p-values were determined using the Tukey's test, $* * * \mathrm{p}<0.001$. (C) HM cells were stimulated for $5 \mathrm{~min}$ utes with $5 \mathrm{U} / \mathrm{mL}$ Asm or with $\mathrm{H} / \mathrm{S}$ buffer as control (untreated). $10 \mu \mathrm{M} \mathrm{SB} 239063$ was added when indicated. Activation of $\beta 1$ integrin was measured by cytometrical analysis upon staining with FITC-labeled HUTS-4 antibodies. Shown is one representative of 4 experiments in total.

cells after stimulation with Asm (Fig. 7C). In conclusion, these data show that $\mathrm{p} 38 \mathrm{~K}$ is involved in the signaling that leads to activation of $\beta 1$ integrin, and thus promoting adhesion and metastasis.

\section{Discussion}

In the present study we investigated sig-

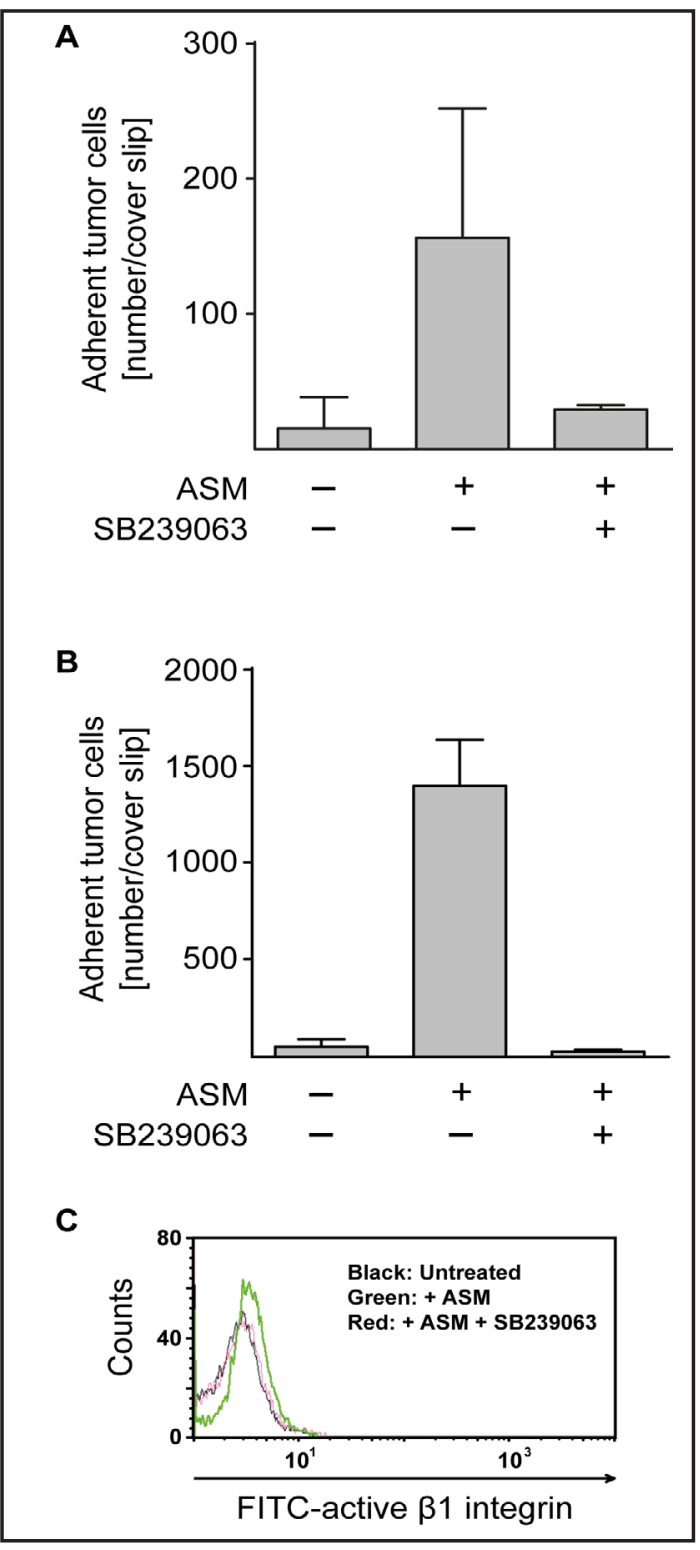
naling events induced in murine and human melanoma cells by exogenous sphingomyelinase. We have previously shown that the interaction of melanoma cells with platelets results in the release of Asm from platelets and that the secreted Asm acts on the surface of the tumor cells to generate ceramide. Ceramide forms ceramide-enriched membrane platforms that serve to cluster and activate integrin molecules in the malignant melanoma cells. The clustering and activation of integrins in ceramide-enriched domains were shown to be necessary for adhesion of the tumor cells to endothelial cells in vitro and in vivo [9]. However, although the results of these studies demonstrated that integrins, regulated by ceramide, play a crucial role in tumor cell metastasis, they certainly do not exclude the possibility that other signaling events are elicited by ceramide and contribute to melanoma metastasis. The studies also did not define any intermediates between ceramide and integrins. In the study reported here, we investigated such signaling events and found that exogenous acid sphingomyelinase induces activation-associated phosphorylation of PLC $\gamma, \mathrm{p} 38 \mathrm{~K}$, ezrin, and ERK, whereas Asm does not affect the phosphorylation/activation of JNK, c-Jun, PI3K, and FAK; in fact, it even decreases the phosphorylation and, thereby, the activity of Akt in melanoma cells. The importance of Asm in the activation of $\mathrm{p} 38 \mathrm{~K}$ was shown by the co-incubation of wild-type and Asm-deficient platelets with melanoma cells. These experiments demonstrated that 


\section{Cellular Physiology Cell Physiol Biochem 2016;38:01-14

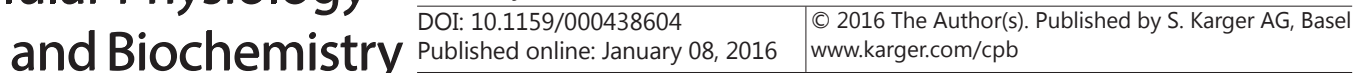 \\ Carpinteiro et al.: Acid Sphingomyelinase-Induced Signaling in Tumor Metastasis}

p38K activation within tumor cells strictly depends on Asm expression in platelets. In contrast, the phosphorylation of ezrin and FAK also occurred after the co-incubation of B16F10 melanoma cells with Asm-deficient platelets, a finding indicating that phosphorylation of these proteins can be triggered not only by pathways induced by exogenous sphingomyelinase, but also by pathways independent of this enzyme when platelets contact tumor cells. In particular, our data indicate phosphorylation of ezrin in tumor cells after the addition of exogenous Asm, but also upon contact with Asm-deficient platelets. This discrepancy can be explained by the following scenario: While exogenous Asm induces S1P formation in tumor cells [31], the physiological contact of wild-type or Asm-deficient platelets with tumor cells leads to the release of S1P that is stored within platelets [32]. S1P then induces the phosphorylation of ezrin [31]. Thus, ezrin-phosphorylation depends on S1P, which can be either secreted from platelets independent of the Asm or formed from ceramide after pharmacological treatment of the tumor cells with Asm.

We further investigated the significance of the Asm-induced activation of $\mathrm{p} 38 \mathrm{~K}$ in vivo and in vitro. Therefore, we inhibited the activity of p38K with SB239063, which is a reversible inhibitor of p38K. It has been shown that the IC50 of SB239063 to inhibit p38K is 44nM. Furthermore, even at the dosage of $10 \mu \mathrm{M}$, which we used, no significant inhibition of other tyrosine kinases was detected [33]. We found that pharmacological inhibition of the activity of p38K prevents early adhesion of B16F10 melanoma cells to endothelial cells in vivo and tumor metastasis, as determined by measurements of macroscopically visible metastases 14 days after the intravenous injection of tumor cells. Although the final read-out is metastatic growth in the lung after 14 days, this long-term outcome is determined by the platelet-tumor cell interaction and the subsequent tumor cell activation/adhesion to endothelial cells occurring within seconds to minutes after platelet-tumor cell contact. The tumor cells that do not adhere are degraded in the host, most likely by natural killer cells [2-4]. Furthermore, we performed in vitro adhesion assays. We show that incubation of tumor cells with Asm increases the adhesiveness of tumor cells on fibrinogen coated glass cover slip, an effect that is nearly completely reverted by the pharmacological inhibition of p38K. Additionally, we measured activation of $\beta 1$ integrin on melanoma cells using the HUTS-4 antibody, which specifically detects activated $\beta 1$ integrin. Co-incubation of tumor cells with Asm leads to an activation of $\beta 1$ integrin on the cell surface, an effect which is again completely reverted by the pharmacological inhibition of $\mathrm{p} 38 \mathrm{~K}$.

Our data indicate a signaling cascade from the Asm via $\mathrm{p} 38 \mathrm{~K}$ to the activation of $\beta 1$ integrin on the cell surface finally executing tumor cell adhesion. Since the latter is the prerequisite for the formation of metastasis in the lung, these findings clearly demonstrate the importance of $\mathrm{p} 38 \mathrm{~K}$ activation for tumor metastasis in vivo.

At present, the exact function of $\mathrm{p} 38 \mathrm{~K}$ in the process of tumor cell adhesion and metastasis is unknown. Our data suggest that $\mathrm{p} 38 \mathrm{~K}$ is involved in the inside-out signaling of $\beta 1$ integrins and, thus, is involved in the activation of integrins, which then mediate tumor cell adhesion. On the other hand, p38K may be still part of the machinery activated by integrins after they cluster in ceramide-enriched domains. p38K may transfer the signal from integrins to the cytoskeleton, in particular the actin cytoskeleton, which has previously been shown to be regulated by p38K [34, 35]. Furthermore, p38K might be regulated by as yet unknown signaling events that are independent of integrins and that link ceramide and ceramide-enriched membrane domains to $\mathrm{p} 38 \mathrm{~K}$, which may be required for tumor cell metastasis, for instance by regulation of the cytoskeleton.

In addition to the regulation of elements in the cytoskeleton, p38K may also be involved in gene regulation, as previously shown for the upregulation in expression of some molecules and receptors that mediate tumor cell invasion, in particular urokinase plasminogen activator/urokinase-specific surface receptor and metalloproteases [36, 37]. However, because p38K inhibitors immediately prevented the adhesion of B16F10 cells, a mechanism involving transcription and/or translation seems unlikely.

P38K may also be involved in the rapid upregulation of the expression of adhesion receptors, such as intercellular adhesion molecule 1 (ICAM-1), upon the activation of ma- 


\section{Cellular Physiology Cell Physiol Biochem 2016;38:01-14 \\ \begin{tabular}{l|l} 
and Biochemistry Published online: January 08, 2016 & $\begin{array}{l}\text { DOI: } 2016 \text { The Author(s). Published by S. Karger AG, Basel } \\
\text { www.karger.com/cpb }\end{array}$
\end{tabular} \\ Carpinteiro et al.: Acid Sphingomyelinase-Induced Signaling in Tumor Metastasis}

lignant tumor cells, perhaps by mobilizing intracellular storage vesicles that contain these receptors [38].

Finally, it may be possible that the activation of p38K is involved in the formation and the release of cytokines, such as IL-1 or TNF- $\alpha$, that act locally on the endothelial cells in the lungs to change the expression of adhesion molecules in the luminal layer of the plasma membrane to allow the tumor cells to adhere to endothelial cells and metastasize [39].

A previous study found that $\mathrm{p} 38 \mathrm{~K}$ expression in platelets and endothelial cells is important for tumor cell metastasis [21], whereas our study focused on the role of p38K expression in the malignant tumor cells. Therefore, $\mathrm{p} 38 \mathrm{~K}$ may be involved in different pathways that mediate tumor cell metastasis in benign host cells and malignant tumor cells.

It seems very unlikely that ceramide directly regulates any of the signaling molecules that were identified in the present study. Ceramide generated by extracellular sphingomyelinase localizes into the outer leaflet of the plasma membrane, whereas the identified signaling molecules are cytoplasmic proteins. It seems much more likely that the effects of ceramide are mediated by ceramide-enriched membrane domains that form after the generation and clustering of ceramide, and may serve to trap receptors and signaling molecules that then transfer the signal into the cell. The ability of ceramide-enriched membrane domains to cluster proteins is very likely to be mediated by their biophysical properties. Thus, ceramide-enriched membrane domains are tightly packed, and stable ceramide-enriched membrane domains are highly hydrophobic and may even exist in a liquid ordered state, which may facilitate the trapping of specific proteins in these domains. Our studies have shown that ceramide-enriched membrane platforms trap and cluster receptor molecules, a process resulting in as much as a 100 -fold amplification of signal transduction of the cognate receptor. The formation of ceramide-enriched membrane domains is triggered by many diverse receptors and stimuli, including CD95 [40, 41], CD40 [42], DR5 [43], Fc $\gamma$ RII [44], PAF receptor [45], CD14 [46], nicotinamide adenine dinucleotide phosphate (NADPH) oxidases [47]; infection with P. aeruginosa [48], S. aureus [49], N. gonorrhoeae [50], measles virus [51], or Rhinovirus [52]; and the application of $\gamma$ irradiation [53, 54], UV light [55], $\mathrm{Cu}^{2+}$ [56], cisplatin [57], or gemcitabine [58]. The reorganization properties of these platforms can be used for signaling. Because p38K is activated by reactive oxygen species (ROS) [59], the clustering of NADPH oxidases in ceramide-enriched membrane domains of melanoma cells after exposure to extracellular sphingomyelinase or upon incubation with wild-type platelets may result in the increased production and release of ROS. These ROS may then trigger the activation of p38K and thereby reorganize the cytoskeleton of the tumor cells to allow adhesion and metastasis.

At present, the molecular mechanisms that mediate receptor clustering are largely unknown. In previous studies we used chimeric constructs of CD40 and CD 45 because of the observation that CD40 clusters in ceramide-enriched membrane domains whereas CD45 does not [60]. The results of these studies showed that the transmembranous domain of CD40 determines receptor clustering [60]. However, the molecular details of that process have not yet been defined.

In summary, we found that stimulating mouse and human melanoma cells with extracellular sphingomyelinase or with wild-type platelets that release Asm results in the activation of $\mathrm{p} 38 \mathrm{~K}$ within the tumor cells, whereas co-incubating the tumor cells with Asm-deficient platelets fails to activate $\mathrm{p} 38 \mathrm{~K}$. Inhibition of $\mathrm{p} 38 \mathrm{~K}$ activity prevents tumor cell trapping and metastasis in the lung in vivo, a finding suggesting the importance of $\mathrm{p} 38 \mathrm{~K}$ activation via sphingomyelinase induced ceramide accumulation for tumor metastasis. Since inhibiting the activity of the kinase acutely reduces tumor metastasis, this kinase may also serve as a novel pharmacological target for preventing the immediate spread of tumor cells, for instance during manipulation of a tumor during a surgical procedure. P38K inhibitors were used in clinical trials for other indications, like for example chronic obstructive lung disease and rheumatoid arthritis, and have been show to be well tolerable $[61,62]$. Thus, inhibition of p38K might be a novel approach to prevent tumor metastasis. 


\section{Cellular Physiology Cell Physiol Biochem 2016;38:01-14 \begin{tabular}{l|l} 
and Biochemistry Published online: January 08, 2016 & $\begin{array}{l}\text { C) } 2016 \text { The Author(s). Published by S. Karger AG, Basel } \\
\text { www.karger.com/cpb }\end{array}$
\end{tabular} \\ Carpinteiro et al.: Acid Sphingomyelinase-Induced Signaling in Tumor Metastasis}

\section{Acknowledgments}

We thank F. Witte and S. Harde for excellent help with the manuscript and with animal experiments. This study was supported by DFG grant Gu 335/24-1 to EG.

\section{Disclosure Statement}

The authors have nothing to disclose.

\section{References}

1 Mehlen P, Puisieux A: Metastasis: A question of life or death. Nat Rev Cancer 2006;6:449-458.

2 Wiltrout RH, Herberman RB, Zhang SR, Chirigos MA, Ortaldo JR, Green KM, Jr., Talmadge JE: Role of organ-associated NK cells in decreased formation of experimental metastases in lung and liver. J Immunol 1985;134:4267-4275.

3 Nieswandt B, Hafner M, Echtenacher B, Mannel DN: Lysis of tumor cells by natural killer cells in mice is impeded by platelets. Cancer Res 1999;59:1295-1300.

4 Shin T, Nakayama T, Akutsu Y, Motohashi S, Shibata Y, Harada M, Kamada N, Shimizu C, Shimizu E, Saito T, Ochiai T, Taniguchi M: Inhibition of tumor metastasis by adoptive transfer of IL-12-activated V $\alpha 14$ NKT cells. Int J Cancer 2001;91:523-528.

5 Gasic GJ, Gasic TB, Stewart CC: Antimetastatic effects associated with platelet reduction. Proc Natl Acad Sci U S A 1968;61:46-52.

6 Gasic GJ, Gasic TB, Galanti N, Johnson T, Murphy S: Platelet-tumor-cell interactions in mice. The role of platelets in the spread of malignant disease. Int J Cancer 1973;11:704-718.

7 Crissman JD, Hatfield JS, Menter DG, Sloane B, Honn KV: Morphological study of the interaction of intravascular tumor cells with endothelial cells and subendothelial matrix. Cancer Res 1988;48:4065-4072.

8 Lonsdorf AS, Krämer BF, Fahrleitner M, Schönberger T, Gnerlich S, Ring S, Gehring S, Schneider SW, Kruhlak MJ, Meuth SG, Nieswandt B, Gawaz M, Enk AH, Langer HF: Engagement of $\alpha$ IIb $\beta 3$ (GPIIb/IIIa) with $\alpha v \beta 3$ integrin mediates interaction of melanoma cells with platelets: A connection to hematogenous metastasis. J Biol Chem 2012;287:2168-2178.

9 Carpinteiro A, Becker KA, Japtok L, Hessler G, Keitsch S, Pozgajova M, Schmid KW, Adams C, Müller S, Kleuser B, Edwards MJ, Grassmé H, Helfrich I, Gulbins E: Regulation of hematogenous tumor metastasis by acid sphingomyelinase. EMBO Mol Med 2015;7:714-734.

10 Ren L, Hong SH, Cassavaugh J, Osborne T, Chou AJ, Kim SY, Gorlick R, Hewitt SM, Khanna C: The actin-cytoskeleton linker protein ezrin is regulated during osteosarcoma metastasis by PKC. Oncogene 2009;28:792802.

11 Ren L, Hong SH, Chen QR, Briggs J, Cassavaugh J, Srinivasan S, Lizardo MM, Mendoza A, Xia AY, Avadhani N, Khan J, Khanna C: Dysregulation of ezrin phosphorylation prevents metastasis and alters cellular metabolism in osteosarcoma. Cancer Res 2012;72:1001-1012.

12 Sulzmaier FJ, Jean C, Schlaepfer DD: Fak in cancer: Mechanistic findings and clinical applications. Nat Rev Cancer 2014;14:598-610.

13 Rebecchi MJ, Pentyala SN: Structure, function, and control of phosphoinositide-specific phospholipase C. Physiol Rev 2000;80:1291-1335.

14 Sala G, Dituri F, Raimondi C, Previdi S, Maffucci T, Mazzoletti M, Rossi C, Iezzi M, Lattanzio R, Piantelli M, Iacobelli S, Broggini M, Falasca M: Phospholipase Cgamma1 is required for metastasis development and progression. Cancer Res 2008;68:10187-10196.

15 Schmid MC, Franco I, Kang SW, Hirsch E, Quilliam LA, Varner JA: PI3-kinase $\gamma$ promotes Rap1a-mediated activation of myeloid cell integrin $\alpha 4 \beta 1$, leading to tumor inflammation and growth. PLoS One 2013;8:e60226.

16 Gawecka JE, Young-Robbins SS, Sulzmaier FJ, Caliva MJ, Heikkila MM, Matter ML, Ramos JW: Rsk2 protein suppresses integrin activation and fibronectin matrix assembly and promotes cell migration. J Biol Chem 2012;287:43424-43437.

17 Sulzmaier FJ, Ramos JW: Rsk isoforms in cancer cell invasion and metastasis. Cancer Res 2013;73:60996105.

18 Roussel L, Houle F, Chan C, Yao Y, Berube J, Olivenstein R, Martin JG, Huot J, Hamid Q Ferri L, Rousseau S: IL-17 promotes p38 MAPK-dependent endothelial activation enhancing neutrophil recruitment to sites of inflammation. J Immunol 2010;184:4531-4537. 


\section{Cellular Physiology Cell Physiol Biochem 2016;38:01-14 \begin{tabular}{l|l} 
and Biochemistry & DOI: 10.1159/000438604 \\
Published online: & $\begin{array}{l}\text { C } 2016 \text { The Author(s). Published by S. Karger AG, Basel } \\
\text { www.karger.com/cpb }\end{array}$
\end{tabular} \\ Carpinteiro et al.: Acid Sphingomyelinase-Induced Signaling in Tumor Metastasis}

19 Tremblay PL, Auger FA, Huot J: Regulation of transendothelial migration of colon cancer cells by e-selectinmediated activation of p38 and ERK MAP kinases. Oncogene 2006;25:6563-6573.

20 Reyes-Reyes ME, George MD, Roberts JD, Akiyama SK: P-selectin activates integrin-mediated colon carcinoma cell adhesion to fibronectin. Exp Cell Res 2006;312:4056-4069.

21 Matsuo Y, Amano S, Furuya M, Namiki K, Sakurai K, Nishiyama M, Sudo T, Tatsumi K, Kuriyama T, Kimura S, Kasuya Y: Involvement of p38alpha mitogen-activated protein kinase in lung metastasis of tumor cells. J Biol Chem 2006;281:36767-36775.

22 Liu-Bryan R, Pay S, Schraufstatter IU, Rose DM: The CXCR1 tail mediates beta1 integrin-dependent cell migration via map kinase signaling. Biochem Biophys Res Commun 2005;332:117-125.

23 Heinrich M, Wickel M, Schneider-Brachert W, Sandberg C, Gahr J, Schwander R, Weber T, Saftig P, Peters C, Brunner J, Krönke M, Schütze S: Cathepsin D targeted by acid sphingomyelinase-derived ceramide. EMBO J 1999; 18: 5252-63.

24 Huwiler A, Johansen B, Skarstad A, Pfeilschifter J: Ceramide binds to the CaLB domain of cytosolic phospholipase A2 and facilitates its membrane docking and arachidonic acid release. FASEB J 2001;15:7-9.

25 Zhang Y, Yao B, Delikat S, Bayoumy S, Lin XH, Basu S, McGinley M, Chan-Hui PY, Lichenstein H, Kolesnick R: Kinase suppressor of ras is ceramide-activated protein kinase. Cell 1997;89:63-72.

26 Dobrowsky RT, Hannun YA: Ceramide-activated protein phosphatase: Partial purification and relationship to protein phosphatase 2A. Adv Lipid Res 1993;25:91-104.

27 Huwiler A, Fabbro D, Pfeilschifter J: Selective ceramide binding to protein kinase C-alpha and -delta isoenzymes in renal mesangial cells. Biochemistry 1998;37:14556-14562.

28 Müller G, Ayoub M, Storz P, Rennecke J, Fabbro D, Pfizenmaier K: Pkc zeta is a molecular switch in signal transduction of TNF-alpha, bifunctionally regulated by ceramide and arachidonic acid. EMBO J 1995;14:1961-1969.

29 Sentelle RD, Senkal CE, Jiang W, Ponnusamy S, Gencer S, Selvam SP, Ramshesh VK, Peterson YK, Lemasters JJ, Szulc ZM, Bielawski J, Ogretmen B: Ceramide targets autophagosomes to mitochondria and induces lethal mitophagy. Nat Chem Biol 2012;8:831-838.

30 Mukhopadhyay A, Saddoughi SA, Song P, Sultan I, Ponnusamy S, Senkal CE, Snook CF, Arnold HK, Sears RC, Hannun YA, Ogretmen B: Direct interaction between the inhibitor 2 and ceramide via sphingolipidprotein binding is involved in the regulation of protein phosphatase $2 \mathrm{~A}$ activity and signaling. FASEB J 2009;23:751-763.

31 Canals D, Jenkins RW, Roddy P, Hernández-Corbacho MJ, Obeid LM, Hannun YA: Differential effects of ceramide and sphingosine 1-phosphate on ERM phosphorylation: Probing sphingolipid signaling at the outer plasma membrane. J Biol Chem 2010;285:32476-32485.

32 Yatomi Y, Ruan F, Hakomori S, Igarashi Y: Sphingosine-1-phosphate: A Platelet-Actinvating Sphingolipid Released From Agonist-Stimulated Human Platelets. Blood 1995;86:193-02

33 Barone FC, Irving EA, Ray AM, Lee JC, Kassis S, Kumar S, Badger AM, White RF, McVey MJ, Legos JJ, Erhardt JA, Nelson AH, Ohlstein EH, Hunter AJ, Ward K, Smith BR, Adams JL, Parsons AA: Sb 239063, a secondgeneration p38 mitogen-activated protein kinase inhibitor, reduces brain injury and neurological deficits in cerebral focal ischemia. J Pharmacol Exp Ther 2001;296:312-321.

34 Guay J, Lambert H, Gingras-Breton G, Lavoie JN, Huot J, Landry J: Regulation of actin filament dynamics by p38 map kinase-mediated phosphorylation of heat shock protein 27. J Cell Sci 1997;110 ( Pt 3):357-368.

35 Huot J, Houle F, Rousseau S, Deschesnes RG, Shah GM, Landry J: SAPK2/p38-dependent f-actin reorganization regulates early membrane blebbing during stress-induced apoptosis. J Cell Biol 1998;143:1361-1373.

36 Huang S, New L, Pan Z, Han J, Nemerow GR: Urokinase plasminogen activator/urokinase-specific surface receptor expression and matrix invasion by breast cancer cells requires constitutive p38alpha mitogenactivated protein kinase activity. J Biol Chem 2000;275:12266-12272.

37 Chen J, Baskerville C, Han Q, Pan ZK, Huang S: Alpha(v) integrin, p38 mitogen-activated protein kinase, and urokinase plasminogen activator are functionally linked in invasive breast cancer cells. J Biol Chem 2001;276:47901-47905.

38 Zhang P, Goodrich C, Fu C, Dong C: Melanoma upregulates ICAM-1 expression on endothelial cells through engagement of tumor CD44 with endothelial E-selectin and activation of a PKC $\alpha$-p38-SP-1 pathway. FASEB J 2014;28:4591-4609.

39 De Cesaris P, Starace D, Riccioli A, Padula F, Filippini A, Ziparo E: Tumor necrosis factor-alpha induces interleukin- 6 production and integrin ligand expression by distinct transduction pathways. J Biol Chem 1998;273:7566-7571.

40 Grassme H, Jekle A, Riehle A, Schwarz H, Berger J, Sandhoff K, Kolesnick R, Gulbins E: CD95 signaling via ceramide-rich membrane rafts. J Biol Chem 2001;276:20589-20596. 


\section{Cellular Physiology Cell Physiol Biochem 2016;38:01-14

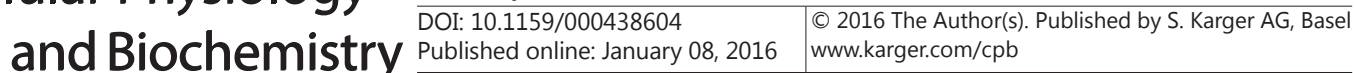 \\ Carpinteiro et al.: Acid Sphingomyelinase-Induced Signaling in Tumor Metastasis}

41 Grassmé H, Schwarz H, Gulbins E: Molecular mechanisms of ceramide-mediated CD95 clustering. Biochem Biophys Res Commun 2001;284:1016-1030.

42 Grassmé H, Jendrossek V, Bock J, Riehle A, Gulbins E: Ceramide-rich membrane rafts mediate CD40 clustering. J Immunol 2002;168:298-307.

43 Dumitru CA, Gulbins E: Trail activates acid sphingomyelinase via a redox mechanism and releases ceramide to trigger apoptosis. Oncogene 2006;25:5612-5625.

44 Abdel Shakor AB, Kwiatkowska K, Sobota A: Cell surface ceramide generation precedes and controls fcgammaRII clustering and phosphorylation in rafts. J Biol Chem 2004;279:36778-36787.

45 Göggel R, Winoto-Morbach S, Vielhaber G, Imai Y, Lindner K, Brade L, Brade H, Ehlers S, Slutsky AS, Schütze S, Gulbins E, Uhlig S: PAF-mediated pulmonary edema: A new role for acid sphingomyelinase and ceramide. Nat Med 2004;10:155-160.

46 Pfeiffer A, Böttcher A, Orsó E, Kapinsky M, Nagy P, Bodnár A, Spreitzer I, Liebisch G, Drobnik W, Gempel K, Horn M, Holmer S, Hartung T, Multhoff G, Schütz G, Schindler H, Ulmer AJ, Heine H, Stelter F, Schütt C, Rothe G, Szöllôsi J, Damjanovich S, Schmitz G: Lipopolysaccharide and ceramide docking to CD14 provokes ligand-specific receptor clustering in rafts. Eur J Immunol 2001;31:3153-3164.

47 Zhang Y, Li X, Carpinteiro A, Gulbins E: Acid sphingomyelinase amplifies redox signaling in pseudomonas aeruginosa-induced macrophage apoptosis. J Immunol 2008;181:4247-4254.

48 Grassmé H, Jendrossek V, Riehle A, von Kürthy G, Berger J, Schwarz H, Weller M, Kolesnick R, Gulbins E: Host defense against pseudomonas aeruginosa requires ceramide-rich membrane rafts. Nat Med 2003;9:322-330.

49 Esen M, Schreiner B, Jendrossek V, Lang F, Fassbender K, Grassmé H, Gulbins E: Mechanisms of staphylococcus aureus induced apoptosis of human endothelial cells. Apoptosis 2001;6:431-439.

50 Grassmé H, Gulbins E, Brenner B, Ferlinz K, Sandhoff K, Harzer K, Lang F, Meyer TF: Acidic sphingomyelinase mediates entry of N. gonorrhoeae into nonphagocytic cells. Cell 1997;91:605-615.

51 Gassert E, Avota E, Harms H, Krohne G, Gulbins E, Schneider-Schaulies S: Induction of membrane ceramides: A novel strategy to interfere with T lymphocyte cytoskeletal reorganisation in viral immunosuppression. PLoS Pathog 2009;5:e1000623.

52 Grassmé H, Riehle A, Wilker B, Gulbins E: Rhinoviruses infect human epithelial cells via ceramide-enriched membrane platforms. J Biol Chem 2005;280:26256-26262.

53 Santana P, Pena LA, Haimovitz-Friedman A, Martin S, Green D, McLoughlin M, Cordon-Cardo C, Schuchman EH, Fuks Z, Kolesnick R: Acid sphingomyelinase-deficient human lymphoblasts and mice are defective in radiation-induced apoptosis. Cell 1996;86:189-199.

54 Paris F, Fuks Z, Kang A, Capodieci P, Juan G, Ehleiter D, Haimovitz-Friedman A, Cordon-Cardo C, Kolesnick R: Endothelial apoptosis as the primary lesion initiating intestinal radiation damage in mice. Science 2001;293:293-297.

55 Zhang Y, Mattjus P, Schmid PC, Dong Z, Zhong S, Ma WY, Brown RE, Bode AM, Schmid HH, Dong Z: Involvement of the acid sphingomyelinase pathway in uva-induced apoptosis. J Biol Chem 2001;276:11775-11782.

56 Lang PA, Schenck M, Nicolay JP, Becker JU, Kempe DS, Lupescu A, Koka S, Eisele K, Klarl BA, Rübben H, Schmid KW, Mann K, Hildenbrand S, Hefter H, Huber SM, Wieder T, Erhardt A, Häussinger D, Gulbins E, Lang F: Liver cell death and anemia in wilson disease involve acid sphingomyelinase and ceramide. Nat Med 2007;13:164-170.

57 Lacour S, Hammann A, Grazide S, Lagadic-Gossmann D, Athias A, Sergent O, Laurent G, Gambert P, Solary E, Dimanche-Boitrel MT: Cisplatin-induced cd95 redistribution into membrane lipid rafts of HT29 human colon cancer cells. Cancer Res 2004;64:3593-3598.

58 Dumitru CA, Sandalcioglu IE, Wagner M, Weller M, Gulbins E: Lysosomal ceramide mediates gemcitabineinduced death of glioma cells. J Mol Med (Berl) 2009;87:1123-1132.

59 Robinson KA, Stewart CA, Pye QN, Nguyen X, Kenney L, Salzman S, Floyd RA, Hensley K: Redox-sensitive protein phosphatase activity regulates the phosphorylation state of p38 protein kinase in primary astrocyte culture. J Neurosci Res 1999;55:724-732.

60 Bock J, Gulbins E: The transmembranous domain of CD40 determines CD40 partitioning into lipid rafts. FEBS Lett 2003;534:169-174.

61 MacNee W, Allan RJ, Jones I, De Salvo MC, Tan LF: Efficacy and safety of the oral p38 inhibitor PH-797804 in chronic obstructive pulmonary disease: A randomised clinical trial. Thorax 2013;68:738-745.

62 Cohen SB, Cheng TT, Chindalore V, Damjanov N, Burgos-Vargas R, Delora P, Zimany K, Travers H, Caulfield JP: Evaluation of the efficacy and safety of pamapimod, a p38 MAP kinase inhibitor, in a double-blind, methotrexate-controlled study of patients with active rheumatoid arthritis. Arthritis Rheum 2009;60:335-344. 